administer standardised research interviews. Scores can be used directly as dimensional measures to examine correlations with other such measures. Another application would be to use the proportion of patients with scores above the cut off scores as an indicator of the prevalence of affective illness in a particular population. The scales could also be administered by medical students to patients on the general wards of hospitals, to make the students more aware of the forms of affective illness common in this setting.

As these scales have been derived from questions administered by a psychiatrist during a research interview they cannot be assumed to perform equally well when administered by non-psychiatrists. Further studies in which patients in a general medical setting are interviewed on separate occasions by a nonpsychiatrist using the new scales and by a psychiatrist using a research interview will confirm the validity of the scales in non-specialist use.

\section{USE OF THE SCALES IN CLINICAL PRACTICE}

The box shows the scales as they might be used by clinicians. Our original interview asked about symptoms experienced in the past month; this period seems realistic for patients in general medical settings. Symptoms that are no longer present, or that are present only in mild degree, should be ignored. Symptoms other than those mentioned here can be asked about, but the score should be obtained from only the symptoms mentioned in the scales. Each question is given the same score, but the items are given in order of increasing severity, so that symptoms further down each scale are encountered in patients with more severe disorders.

The cut off scores given here have been determined in general practice settings; possibly some upward revision may be necessary to obtain the best results among patients on medical or surgical wards. The scales can now be used in clinical settings and compared with results of diagnosis with more time consuming methods.

1 Goldberg DP, Blackwell B. Psychiatric illness in general practice: a detailed study using a new method of case detection. Br.Med f 1970;ii:439-43.

2 Moffic H, Paykel ES. Depression in medical in-patients. Br 7 Psychiatry 1985; 126:346-53.

3 Skuse D, Williams P. Screening for psychiatric disorder. Psychol Med 1984;14:365-78

4 Bridges K, Goldberg DP. Psychiatric illness in patients with neurological disorders: patients' views on discussion of emotional problems with neurologists. Br Med f 1984;289:656-8.

5 Sireling K, Paykel ES, Freeling P. Depression in general practice. $\mathrm{Br} \mathcal{F}$ Psychiatry 1985;141:113-9.

6 Goldberg DP, Bridges K. Screening for psychiatric illness in general practice: the general practitioner versus the screening questionnaire. $f R$ Coll Gen Pract 1987;37:15-8.

7 Brodaty H, Andrews G, Kehoe L. Psychiatric illness in general practice: why is it missed? Aust Fam Physician 1982;11:625-31.

8 Goldberg DP, Steele J, Smith C, Spivey L. Training doctors to recognise psychiatric illness with increased accuracy. Lancet 1980;ii:521-4.

9 Gask L, Goldberg DP, Lesser A, Millar T. Improving the psychiatric skills of the general practice trainee: an evaluation of a group training course. Med the general practice trair

10 Rasch G. Probabilistic models for some intelligence and attainment tests. Copenhagen: Danish Institute of Educational Research, 1960

11 Duncan-Jones P, Grayson D, Moran P. The utility of latent trait models in psychiatry epidemiology. Psychol Med 1986;16:391-405.

12 Goldberg DP, Bridges K, Duncan-Jones P, Grayson D. Dimensions of neuroses seen in primary care settings. Psychol Med 1987;17:461-70.

13 Dean C, Surtees P, Sashidharan S. Comparison of research diagnostic systems in an Edinburgh community sample. Br 7 Psychiatry 1983;142:247-56.

4 American Psychiatric Association. Diagnostic and statistical manual of mental disorders. 3rd ed. Washington, DC: APA, 1980.

15 Zigmond AS, Snaith RP. The hospital anxiety and depression scale. Acta Psychiatr Scand 1983:67:361-70.

16 Goldberg DP, Hillier V. A scaled version of the general health questionnaire. Psychol Med 1978;9:139-45.

17 Hamilton M. The assessment of anxiety states by rating. Br f Med Psychol 1959;32:50-8.

18 Hamilton M. A rating scale for depression. 7 Neurol Neurosurg Psychiatry 1960;23:56-62

19 Goldberg DP, Cooper AB, Eastwood MR, Kedward HB, Shepherd M. A standardised interview suitable for use in community surveys. British Journal of Preventive and Social Medicine 1970;24:18-24

20 Wing JK, Cooper JE, Sartorius N. The measurement and classification of psychiatric symptoms. London: Cambridge University Press, 1974.

(Accepted 8 fune 1988
Department of Clinical

Epidemiology, The London Hospital Medical College, London E1 2AD

T D Spector, $M R C P$,

Wellcome research fellow

A J Silman, FFCM, senior lecturer

\section{Department of}

Rheumatology, St Bartholomew's Hospital, London EC1

GCBrown, BSC, medical student

Correspondence to:

Dr Spector.

\section{Increased rates of previous hysterectomy and gynaecological operations in women with osteoarthritis}

\section{T D Spector, G C Brown, A J Silman}

Osteoarthritis is more common in women around the age of 50 than in men of the same age. 'We investigated in a case-control study possible gynaecological or hormonal influences that might account for this observation.

\section{Patients, methods, and results}

The cases comprised women aged 35-70 with osteoarthritis attending one of six local outpatient clinics. Two groups of similar ages were used for comparison: 314 women with rheumatoid arthritis attending the same clinics and a group drawn from a random sample of 1000 women obtained from electoral registers in Greater London. Subsequently we also studied 346 women from a local general practice. Each woman received a postal questionnaire that contained questions on menarche, menopause, parity, use of the contraceptive pill, hysterectomy, and date of onset of disease when applicable. Diagnoses and gynaecological details in the hospital groups were verified by inspection of medical records. The response rates were $83 \%$ (327) 393 ) in the osteoarthritis group, $91 \%(286 / 316)$ in the rheumatoid arthritis group, and $70 \%$ (243 replies in the age range) in women from the electoral register. Owing to inadequate data the final sample sizes were those shown in the table.

The table shows the main results. Women in the osteoarthritis group reported a higher rate of hysterectomy $(28 \%)$ than those in the rheumatoid arthritis group $(14 \%)$ and population control groups $(15 \%$ and $11 \%$ ). The median time from hysterectomy to diagnosis was six years in the osteoarthritis group and four years in the rheumatoid arthritis group. Further gynaecological information was available for most of these women. Oophorectomy was reported by 24 out of $48(50 \%)$ women with osteoarthritis and 10 out of 25 $(40 \%)$ with rheumatoid arthritis. The commonest surgical indications were menorrhagia or fibroids or both $(45$ out of $57(79 \%)$ with osteoarthritis and 18 out of $29(62 \%)$ with rheumatoid arthritis). There was also a higher rate of dilatation and curettage $(82(42 \%) v 52$ $(26 \%))$ and other gynaecological problems $(110(52 \%) v$ $75(34 \%))$ among the women with osteoarthritis.

The timing of hysterectomy in relation to the onset of disease was examined in the two arthritis groups. The crude relative risk of hysterectomy at least one year before referral to hospital for osteoarthritis was $2 \cdot 8(95 \%$ confidence interval $1 \cdot 7$ to $4 \cdot 6)$. Using age at first symptoms did not alter the estimates. The relative risk adjusted for age was $2.9(1.8$ to 4.7$)$; adjustment for other variables did not appreciably alter the estimate.

\section{Comment}

The increased rate of hysterectomy and other gynaecological operations in women with osteoarthritis 


\begin{tabular}{|c|c|c|c|c|c|c|c|c|c|}
\hline & $\begin{array}{l}\text { No in } \\
\text { group }\end{array}$ & $\begin{array}{c}\text { Median } \\
\text { age } \\
\text { (years) }\end{array}$ & $\begin{array}{c}\text { No }(\%) \\
\text { nulliparous }\end{array}$ & $\begin{array}{c}\text { Median } \\
\text { age at } \\
\text { menopause } \\
\text { (years) }\end{array}$ & $\begin{array}{c}\text { Median age } \\
\text { at onset of } \\
\text { symptoms } \\
\text { (years) }\end{array}$ & $\begin{array}{l}\text { Median age } \\
\text { at referral } \\
\text { (years) }\end{array}$ & $\begin{array}{l}\text { No }(\%) \text { who } \\
\text { had had } \\
\text { hysterectomy }\end{array}$ & $\begin{array}{l}\text { Median age at } \\
\text { hysterectomy } \\
\text { (years) }\end{array}$ & $\begin{array}{l}\text { Median time from } \\
\text { hysterectomy } \\
\text { to referral } \\
\text { (years) }\end{array}$ \\
\hline Osteoarthritis group & 292 & 58 & $52(18)$ & $49 \cdot 5$ & 49 & 53 & $82(28)^{\star}$ & 42 & 6 years \\
\hline Rheumatoid arthritis group & 270 & 59 & $71(27)$ & $49 \cdot 5$ & 48 & 50 & $39(14)^{\star}$ & 45 & 4 years \\
\hline Electoral register population & 243 & 50 & $33(14)$ & 50 & & & $37(15)$ & 43 & \\
\hline Local general practice population & 346 & 54 & $71(29)$ & 50 & & & $38(11)$ & 41 & \\
\hline
\end{tabular}

* Sixty three $(77 \%)$ and $25(64 \%)$ hysterectomies were carried out at least one year before referral to hospital in the osteoarthritis and rheumatoid arthritis groups respectively.

implied that the indications for surgery might be more important than surgery itself. There are several potential biases. Early symptoms in women with osteoarthritis may have been misinterpreted and resulted in hysterectomy. This is unlikely given the long median delay (six years) between operation and diagnosis and that those with spinal osteoarthritis did not have the greatest rate of hysterectomy. The difference in rate of hysterectomy between the women with osteoarthritis and those with rheumatoid arthritis may have been due to fewer gynaecological abnormalities occurring in those with rheumatoid arthritis. Previous studies found no difference between women with rheumatoid women with rheumatoid arthritis were similar to those in our population controls. By contrast, a link between hysterectomy and predisposition to osteoarthritis is biologically plausible. Dysfunctional uterine bleeding and fibroids, the main reasons for hysterectomy in our study, have both been attributed to an excess of oestrogens. ${ }^{3}$ Oestrogens have also been found to affect adversely several different animal models of osteoarthritis, ${ }^{4}$ possibly by affecting turnover of proteoglycan.

\section{Suppression of ovulation by transdermal oestradiol patches}

\author{
N R Watson, J W W Studd, A F Riddle, \\ M Savvas
}

Premenstrual Syndrome

Clinic, Department of

Obstetrics and

Gynaecology, Dulwich

Hospital, London

SE22 8PT

$\mathrm{N} R$ Watson, $\mathrm{MB}$, research

fellow

J W W Studd, MD, consultant gynaecologist

A F Riddle, MRCOG, senior registrar

M Savvas, MRCOG, senior registrar

Correspondence to: Mr Studd

Percutaneous oestrogen is a well tolerated and highly acceptable treatment for symptoms of the menopause. The percutaneous route avoids first pass liver metabolism and the associated changes in hepatic proteins that occur with oral treatment,' particularly with ethinyloestradiol and mestranol, the oestrogens in the contraceptive pill thought to be associated with morbidity. This study was undertaken to determine the effect of transdermal oestradiol patches on ovulation.

\section{Patients, methods, and results}

Ten women attending this clinic (mean age 35 ) who had a regular cycle (28-30 days) and were not using arthritis and controls, ${ }^{2}$ and the rates of hysterectomy in

Our results suggest that although osteoarthritis undoubtedly has a multifactorial aetiology, an underlying imbalance of oestrogen may be responsible for both the gynaecological problems and the development, several years later, of osteoarthritis.

We thank the consultants in rheumatology and staff of the following for their cooperation and help: St Bartholomew's Hospital, The London Hospital, Homerton Hospital, Whipps Cross Hospital, Wanstead Hospital, St Andrew's Hospital, and Wapping Health Centre. We also thank Dr Eve Roman of the London School of Hygiene and Tropical Medicine for giving us access to data on the controls obtained from the electoral register.

1 Lawrence JS. Rheumatism in populations. London: Heinemann, 1977.

2 Short CL, Bauer W, Reynolds WG. Rheumatoid arthritis. Cambridge, Massachusetts: Harvard University Press, 1957

3 Studd J, Thom MH. Oestrogens and endometrial cancer. In: Studd J, ed. Progress in obstetrics and gynaecology. Vol 1. Edinburgh: Churchil Livingstone, 1981:183-98.

4 Rosner IA, Goldberg VM, Moskowitz RW. Estrogens and osteoarthritis. Clin Orthop 1986;213:77-83.

(Accepted 10 June 1988)

transdermal oestradiol patches every three days from the first day of menstruation for three cycles. Monitoring was by ultrasonography on alternate days and assay of luteal phase progesterone and oestradiol concentrations. When the study was completed the patients had an endometrial biopsy and were started on cyclical progestogens to correct excess endometrial proliferation.

The table summarises the results. During the hormonal contraception were selected for the study. They were monitored for four cycles. The first cycle was without treatment to confirm ovulation. Subsequently they were treated with two $100 \mu \mathrm{g}$

Effects of transdermal oestradiol patches on ovulation

\begin{tabular}{lcllc}
\hline & Before treatment & 1st Month & 2nd Month & 3rd Month \\
\hline No who ovulated & 10 & 1 & & \\
No who menstruated (day) & $10(27-30)$ & $1 \star(28)$ & & Spotting \\
Mean (range) oestradiol $(\mathrm{nmol} / \mathrm{l})$ & $0 \cdot 37(0 \cdot 2-0 \cdot 5)$ & $0 \cdot 58(0 \cdot 2-0 \cdot 9)$ & $1 \cdot 1(0 \cdot 2-2 \cdot 9)$ & $0 \cdot 62(0 \cdot 3-0 \cdot 8)$ \\
Mean (range) progesterone $(\mathrm{nmol} / \mathrm{l})$ & $30 \cdot 1(13-81)$ & $2 \cdot 6(0 \cdot 2-7 \cdot 4)^{\star}$ & $0 \cdot 4(0 \cdot 1-1 \cdot 0)$ & $0 \cdot 4(0 \cdot 1-0 \cdot 9)$
\end{tabular}

^Progesterone concentration in the patient who ovulated was $34 \mathrm{nmol} / 1$. 